\title{
Unequal Access to Tertiary Education; Implication for National Security
}

\author{
Oludeyi Olukunle Saheed \\ Department of Sociological Studies, Tai Solarin University of Education, Ogun State, Nigeria
}

\begin{abstract}
This paper examines the growing rate of unequal access to tertiary education among Nigerian youths and its implication for national security. Although bias has existed during the colonial era, recent events reveal high waves of access-inequality and prejudice. Following the trend of violence, terrorism and insecurity in Nigeria today, this paper contends that youth education, reorientation and empowerment organized through unbiased processes are fundamental requisites for socio-economic, political and national security. The paper argues further that the number of youths who enjoy unrestricted access to tertiary education is unequal to the number of those who find it as privilege rather than rights. A significant number of Nigerian youths are illiterate and resultantly gullible to anti-social cajoles courtesy of rapacious and nefarious political leaders who use them as tools for disrupting the nation's political and democratic stability. This is done through rigging, thuggery, and religious violence which are detrimental to national peace and security. The paper therefore, concludes that there is urgent need for government, educational policy makers and stakeholders to repackage educational priorities in such a way to removing all biases preventing youths, especially the poor, from enjoying educational opportunities. This will help, a great deal, in curbing youth's involvement in activities that are inimical to national security.
\end{abstract}

Key words; Access, Crime, Education, Inequality, Security, Youth

\section{Introduction}

There seem to be a gradual neglect, in our discussions, about the inherent inequalities in our selection process for candidates to higher education in Nigeria. This is in spite of the fact that Nigerian administrative and legislative norm provides for equal opportunity and access to education among people irrespective of nationalities, residence and sex. Although educational inequalities is a global phenomenon, Igbuzor, (2006) and Subrahmanian, (2002) have documented that "across the globe, there are inequalities in educational access and achievement as well as high levels of absolute educational deprivation of both children and adults". Meanwhile, education is a human right that should be accorded to all human beings solely by reason of being human" (Igbuzor, 2006) This is in congruent with the goals of university education as stated in the National Policy on Education which among others, aims at "developing intellectual capacity, developing values for the survival of individuals, manpower training, providing enabling and conducive environment as well as acquiring both physical and intellectual skills that will enable individuals to be self-reliant and useful members of the society" (FRN, 2004) It states further that "every Nigerian child shall have rights to equal educational opportunities irrespective of any real or imagined disabilities each according to his or her ability. "The provision of equal access to educational opportunities for all citizens of the country at the primary, secondary, and tertiary levels both inside and outside the formal system is the objective of the policy" (Moti, 2010) and its philosophy is in consonance with the Universal Declaration of Human Rights (1996) which asserts that "everyone has a right to education". Other international human rights instruments (such as the International Covenant on Economic, Social and Cultural Rights (1966); and the African Charter on Human and Peoples' Rights (1981) also recognize education as a fundamental human right. Nigeria, definitely is signatory to all of these conventions and recognizes the importance of education to national development.

However, inequalities and marginalization of various kinds among different social groups represent one of the biggest problems facing Nigerian society today. (Igbuzor, 2006; Subrahmanian, 2002) Educational opportunities have been reshuffled and the role of higher education has been transformed. The pursuit of educational goal is rapidly going down the drain. Consequently, educational standard in Nigeria today is being accused of incapable of oiling the wheel of sustainable development. Unfortunately, instead of expanding and equalizing educational opportunities in our country, much of higher educational institutions have simply become platform for showing off social status. A larger portion of the Nigeria population, as a result, lacks access to tertiary education. Literacy level in the country has resultantly deteriorated, especially within the age group of 15 and 24. (NMDG, 2005) This is highly discouraging because certain socio-economic and institutional factors, among others, prevent majority from being educated. "In fact the disparity in access to education in Nigeria takes several forms; from gender disparities in the educational systems to disparities between demand and 
supply, disparities between urban and rural schools, and between educational institutions owned and controlled by the Federal Government and those owned and controlled by the States and private agencies. The list is endless". (Ofoha, 2011) The argument here is that whether these pull of illiterates lacks access to education based on constraint of accessibility, affordability or admissibility or base on designed denials in educational system, it surely must have significant effect on the socio-economic and political stand of the nation.

The above issue becomes significant with the recent ubiquitous of terrorism, youth restiveness, hooliganisms and other socio-political vices experienced in Nigerian today. "An idle mind they say is devil's workshop"; it is 'devil in action' when such mind is youth's. Hence, it becomes imperative that this topic should cease from being neglected for the sake of Nigerian economic development and socio-political security. It is in the light of this that this paper strives to discus inequality in access to tertiary education with a view to establishing its possible impact on the state of Nigerian national security.

\section{Conceptualizing Inequality and Access to Tertiary Education in Nigeria}

As far back as 1959, equal opportunity for access to tertiary education had been articulated by the Ashby Commission as a problem of concern to all. The commission was particular about regional inequality in educational opportunities i.e., the imbalance in educational opportunities between the southern and northern parts of the country. The National Policy on Education (NPE, 2004) defines access as "making it possible for everyone who is entitled to education to receive it". UNESCO (2003) also defines access to tertiary education as "ensuring equitable access to tertiary education institutions which is based on merit, capacity, efforts and perseverance..." Ene (2005) conceptualised equity in education as "ensuring that all the segments of the society get fair share of whatever educational opportunities are provided". It is on this note that Moti (2010) summarised it that "access implies opportunity for formal education" while "equity is fairness in admission".

On the other hand, inequality in educational access, involves barriers based on accessibility, affordability or admissibility constraints which prevent individual from enjoying equal opportunity in gaining and obtaining tertiary education. Equality, or equal opportunity, first and foremost, relates to access, and in this case, access to higher education, i.e. whether all students interested in or enrolling in higher education can do so. Equality is primarily restricted by the limited capacities of higher education institutions. In the context of Nigerian, inequality in educational access can be seen as an institutionalized educational prejudice and designed denials arising from imbalance social status and unequal competition for scarce resources. The outgrowth of the socio-economic structure which perpetuates inequalities in access to resources in the society incidentally renders tertiary education as yardstick for determining social class and financial power in the society. Unequal access to education therefore describes a situation where higher institutions of learning have become increasingly biased in the manner in which they admit students. The idea of equality with reference to education, in the words of Ofoha (2011) means "equal rights for all irrespective of any circumstances by way of birth, race, sex, tribe, and disability". As argued by Salawu (1995), cited in Ofoha (2011) the idea of equality means that "all persons are born equal and are treated equally irrespective of their social status". However, he added that "nature itself initiates inequality and therefore not every inequality is unjust". Educational inequality arising from difference in choices, ability and virtues are just, while educational inequality prompted by sex, social class, and race, state of origin, disability, and religion, is unjust.

The Nigerian story of inequality and access to tertiary institution is highly disheartening. "Today, less than $20 \%$ of those who apply to the universities is admitted" (Moti, 2010) and this has become a subject of concern to all who appreciates the value of higher education in Nigeria. Scarier is the current trends of widened imbalance in access. Igbuzor, (2006) and the UNDP (2005) documents that "if current trends continue, the target of achieving universal education by 2015 will be missed by at least a decade. There will be 47 million children out of school in 2015, 19 million of them in Sub-Saharan Africa. Forty six countries are going backwards or will not meet the target until after 2040. These countries account for 23 million of the 110 million children currently out of school in developing countries". Ilusanya (2008), and Moti (2010), see issue of educational access in Nigeria as politics noting that "variations in educational development between the southern and northern parts in Nigeria had necessitated the introduction of certain policies to engender even national representation in institutions nationally owned". It is in the same line of thinking that Akpotu (2005) opines that "the major obstacles to increased access to higher education in Nigeria are not prices but the reform policies of quota system, catchment area admission policy, poor and inadequate facilities and the limited absorptive capacity of Nigerian universities".

\section{Education and Youths Restiveness}

Education, according to Anugwom (2009) "generally concerns itself with the imparting of knowledge in people". Knowledge in this case can be seen as the corpus of instruction and social ethos, which hinges on the acquisition of abstract ideas needed for refined minds and psycho-motor skills acquisition. This in turn makes one a skilled person or at least positions one in the right frame of mind to acquire the skill necessary for 
existence in an atomized social order. It is a process through which a person acquires knowledge, skills, habits and values that enables him to function effectively as a member of the society. Youth restiveness, on the other hand, is the tendency that teenagers in their struggles for socio-economic, political, ethnic, cultural, religious, gender and educational emancipation, constantly and relentlessly get out of, or resist control of authorities.

Whereas, the conventional assumption is that crime ought to decrease with the increased internalization of educational values among educated people, the Nigerian experience present reasons for skepticism especially with her records in youth criminality. When studied properly, it is discoverable that most of the restive youths in Nigeria are the once, who lack educational opportunities and values or the half-trained dropouts. Studies of Egwakhe and Osabuohien (2009) and Anayochukwu (2007) have shown that "the untapped human resources and the decay in the educational sector results in a high propensity to criminal behaviour and violence, especially among the youth". It was also documented (by Wilson \& Herrnstein, 1985; Freeman, 1991) that "criminals tend to be less educated than non-criminals". This was further buttressed by Freeman (1996) whose study was in the US and identified that "two-thirds of the incarcerated men had not graduated from high school". The unwelcome aspect of the episode is that the number of recruits, the density of active crime participants, and the sophistication of operations" (Oni, 2008; and Obe \& Isine, 2008) create an atmosphere of apprehensiveness among the populace (Alemika \& Chukwuma, 2006) in Nigeria. There is steady rise in youth crime, nurtured in a climate of increasing national income. This is couple with a proliferation of Islamic terrorist offshoots. The season of discontent has special ramifications for a nation with unemployed millions, and the net effect has been a tragic precipitation of violent crimes: assault, burglary, extortion and kidnapping. Decades of social and political turmoil have turned this strategically located African nation into an established junction for international drug smugglers. "Other highlights of Nigeria's prolific crime syndicates are economic fraud usually in the form of innovative Internet schemes; money laundering and racketeering". (Osalor, 2010)

Education, being the fulcrum around which quick development of economic, political, sociological and human resources of any country revolves, (Ajobo, 2008) it is in recognition of its importance that the international community and governments all over the world have made commitments for citizens to have access to education. However, regardless of the incontrovertible evidence that education is crucial to the development of the community and the nation, there remain inequalities in access to education. (Ofoha, 2011) Despite its potential for leveling opportunities, education is in many countries, especially Nigeria, used in perpetrating inequalities. Millions of poor people and their children are excluded from the processes and outcomes of education. (Igbuzor, 2006) The implication of this is on national security, and may even be highly crippling. It is therefore safe to conclude that unless all forms of restrictions and access-inequality to tertiary education are removed by way of policy, such vices as hooliganism, hoodlumism, terrorism, prostitution, internet fraud etc, among Nigeria youths cannot be nip in the bud. And subsequently impediments to national security will remain in intense.

\section{The Treacherous Role of UTME}

In spite of its stated objectives of uniformity and fairness that formed the bases of its establishment as stated in the Decree No.2 of 1978, the Joint Admission and Matriculation Board (JAMB) (now Unified Tertiary Matriculation Examination-UTME) plays systematic role in the continued installation of access-inequality into universities in Nigeria. The board was set up to evolve uniform standards for university admissions and to ensure that merit serves as the basis of selection of candidates for admission. However, Obilade (1992) found out a contradiction between the stated goals of JAMB and what is in practice. A quota based system of non academic considerations predominates. JAMB examinations became a political tool to be used for equalising educational opportunities between the advantaged states of the south and disadvantaged states of the North. To this end, JAMB documents specified catchment areas. Catchment area means geographical areas in which higher educational institution is permitted or obliged to select candidates. Debunking the myth behind guideline of catchments and quota system, Obilade (1992) explained that "the pattern of admission requires merit of $45 \%$, catchment area of $35 \%$, disadvantaged areas of $20 \%$ and discretion of $10 \%$ ". While explaining the operational stand of the quota system, Moti (2010) posit that "candidates from Educationally Less Developed or Disadvantaged States (ELDS) most of whom are from northern states are given special concession for admission". However Speaking on potency of the quota system Ofoha (2011) argues that "the system is viewed as a clear case of "robbing Peter to pay Paul" as it has continued to create educational imbalance between the North and the South, engendering ill-feeling and social injustice among its citizens". This however is not without political implications. It forces integration, stifles academic freedom and ends the autonomy of the universities which attracts several resentments by the public. Moti (2010) submits that "the system of admission through JAMB had continued to come under heavy criticisms as various studies conducted continued to reveal no relationship between JAMB entry scores and performance in degree examinations". It is arguable that the board's examination is no longer reliable and should not continue to be used as a predictive instrument in measuring students' performance and competence for university education. Unfortunately the Board recreated 
several other stringent procedures into the process of obtaining admission. Screening took various forms, depending on the approach of the university and this is another problem entirely in the development of higher education. Intending candidates now have multiple hurdles in securing admission into the university system. The hurdles require firstly, passing the senior secondary school certificate examinations, secondly passing the JAMB Examinations and thirdly passing the University of Choice Screening Tests". Since JAMB is used politically as tool for influencing admission processes, government has refused to scrap it, yet refuse to make the needed adjustment. This is in spite of the fact that the board continues to widen the gap of unequal access to post-secondary education; benefitting the children of the Haves at the detriment of the Have-nots. Unfortunately the song still tends to continue in a more resounding tone with the establishment of Unified Tertiary Matriculation Examinations (UTME). It means that the instrumental roles played by the board, which were limited to universities, now enjoy extension to all tertiary institutions across the federation. The UTME again, is an old wine in a new bottle.

\section{Historical Overview of Factors Undermining Equal Access to Tertiary Education in Nigeria}

An overview of how these educational denials were systematically and progressively designed is not irrelevant. It is important so that we can together know where and how to retrace our footsteps and begin to resolve the problems.

1 The Antecedent: Prior to Nigerian independent, the process of human resource development for national growth according to Ekpo, (1989) was distorted by colonialism with the attendant negative orientation that was injected into political leadership. Manpower development as a result, became an elitist design geared to favour capitalist mode of production in which labour was relegated to the background among the factors of production. It is arguable that there were distortions in both the concept and method of manpower development in the Nigerian state as it was oriented towards serving capitalist interest. This accounts for the discrepancies in the utilizations of educational systems, access and deliveries to serve national interest in Nigeria. Thus, manpower development became an elitist design that was geared to favour the affluent few, living majority disadvantaged. Unfortunately this template of unequal access created during this era was hardly noticed because people did not crave tertiary education as they do today.

Ten years after independent and up to mid 80's, the five premier universities (Ahmadu Bello University, Zaria; University of Ibadan, University of Ife, University of Lagos, and University of Nsukka) were centers of academic excellence. In the words of Odetunde (2006) "there were few universities and many students to be admitted... Many students with grade II found it difficult to gain admission because there were so many excellent students to pick from and competition was very fierce but healthy. During the Gowon era, prices skyrocketed, (including school fees) and then crude oil became the only way that Nigeria generated her revenue. Gaps in financial power for educational access were a little widen. The realization that the problem of multiple admissions into Nigerian universities and the inability of universities to predict their future fresh student population, gave rise to the centralization of university admission, through the creation of Joint Admissions and Matriculation Board (JAMB) in 1978 by military Decree No.2 of 1978. (Moti, 2010) Nigerian government resultantly, began influencing admission standards through the newly established board. They introduced Federal character, catchment areas, etc., without monitoring standard for accessibility, affordability and admissibility. Prospective university students who needed admission simply got letters from the head of state, governors, or ministers in order to gain admission. (Odetunde, 2006) Consequently, some class of students did not work hard to justify the chance of getting admission into high institutions of leanings; while others were simply not opportune despite being potentially the right candidate for admission. Gap became gradually widened keeping many brilliant youths away from tertiary education.

2 The Emergence of Private Institutions: The above scenario became opportunity to some leaders with economic and political power. Public office holders premeditatedly and gradually abandoned their responsibilities of improving the state of education in public schools so many of them began investing their illgotten money in establishing private schools. With the intension of increasing access to tertiary institution government permitted private participation in tertiary education and granted these tycoons licenses to operate universities provided they meet NUC requirements. To a certain extent, according to Moti (2010) the establishment of these private universities would satisfy the qualified candidates who could afford the cost of private universities. The less privileged were, and are still denied access. Unfortunately the student enrolment level of the private universities is comparably low and may not be an immediate solution to the problem of access. Self-seeking visionless leaders who created the new universities did not present viable strategies for absorbing the graduates (Odetunde, 2006); rather they make parents' ability to sponsor private university education another yardstick for measuring social status and class. More disturbing is that the private universities were more conscious of profit-making on education than quality. According to Odetunde (2006) "hard work and excellence was no longer the yardstick by which access was measured but political connection and financial power". Payment of tuition fee was impossible for common man. Again, unequal access to higher education got 
another dimension with new tentacles. Children whose parents were rich or had political connections, and able to pay the fees in private universities started enjoying wide access to education regardless of standards. The elitist educational design, created prior to Nigerian independence became more glaring and impacted mostly on paupers and their wards. The momentum of literacy declination among the mass youths in Nigeria was again with rapidity.

3 Socio-Economic Factors: A careful observation from the antecedent era to the emergence of private institution reveals that major impediment obstructing people from gaining access to tertiary education in Nigeria revolves around money/fees. The major reason why people do not get easy education is not unconnected with finances. According to Igbuzor (2006) "a study conducted by Action Aid published in 2003 showed that the reason why pupils do not go to schools include costs of schooling, illness and hunger, limited economic costs of education and low quality of schooling on the part of the parent. Also the fact that some people who have completed school but have no jobs do dissuade people from going to school". Rose (1989), and Igbuzor (2006) listed the categories of children who tend to be excluded from the formal schooling system to include children from the poorest families, the landless, working children, children of minority groups, children of migrant or pastoralist families, orphans, children affected by HIV/AIDS and those with physical or mental disabilities" This is in accord with researches that have shown that whenever user fees are introduced in the provision of social services, the utilization by the rich increases while utilization by the poor decreases. (Igbuzor, 2006; 1992)

4 Regional Factors and Quota System: It seems palpable that government had made several attempts at correcting the imbalance in access to tertiary education in Nigeria. Among other ways used by government was the introduction of the quota system to admission processes. This was specifically geared towards helping the Educationally Less Developed States (ELDS) most of whom are northerners. (Moti, 2010) Meanwhile the educational gap between Northern and Southern Nigeria is tantamount to a trace of educational inequality, which started since the beginning of western education. (Ofoha, 2011) Candidates form the ELDS are given special consideration during admission processes. The Tertiary Institutions assign lower cut-off marks to this category of candidates so that they can be given opportunity to forestall a lopsided development of education in the country. By this system, it means that a candidate in the southern states (considered to be educationally advantaged) who scores 280 out of 400 may not get admission into the university while his counterpart in the north who scores less would be admitted. Much as it is good that the educationally disadvantaged areas are being encouraged, it should not be at the detriment of eligible others. A situation where a candidate does not gain access just because of his birth place is not too good. (Moti, 2010) This is why Akpan and Undie (2007) contends that using the quota system to guide and regulate access to university education has an inequitable effect; the entire system reflects privilege and differentiation. This of course represents another source of designed denials from educational opportunities for many Nigerian youth till date.

5 Parental Negligence: Following the rapid increase in number of those who remained at home while their mates head for school; it became less and less shameful to many youths for roaming round streets. After all, they believe, it was not there fault that their parent could not afford to help them secure admission. Was the faults parents'? It is probably not. However they seem to share little in the blame. In the past, parents used to be the backbone of the nation. They taught their children right from wrong, and they also taught them the value of hard work. The cultural and societal implication of literacy was drilled into them. Parents used to deny themselves to provide good university education for their children. This still exist till date but the commitment is comparably low. According to Odetunde (2006) "every parent (probably not all) became a businessperson in oil business chasing after contracts and acquiring more cars and houses while neglecting the moral, social, and academic needs of their children. The rich throw money at every problem while the poor were dissuaded from sending their children to school because they found that many of those who received good education were unable to get employment in the formal sector (Igbuzor, 2006). Further, parents and guardians are reluctant to send their children and wards to dilapidated school buildings to be taught by ill-motivated teachers. They are reluctant to send their children and wards to school when the education that the kids are getting is not in any way relevant to their circumstances, or when there is a danger that they can be abused by teachers or members of the community on their way to school. Many poor parents believe that it is fruitless and expensive to send children to school since the children's time could be of economic importance to the family either in terms of income generating activities or in supporting the functioning of the household. As such, many children were thrown to street hawking; they from there became "street urchins" through which they were initiated to crews of mendicants or what Egwakhe and Osabuohien (2009) refer to as "Area-Boyism". What they probably mean by this term include "a pack of jobless, visionless but energetic youths who form gangs and constitute treat to peaceful atmosphere of Nigeria streets". An advance form of such groups invariably becomes agents of destructions of all kind and major threat to national peace and security.

6 Abuse from Tertiary Institutions: The problem in the university systems is very peculiar. It is a product of the rot in Nigerian educational system as a whole. It started when government started intervening in the 
internal affairs of academic staff during Gowon's administration. The antecedent scenario was traced and captured in Odetude (2006);

\begin{abstract}
“...it was not too surprising that the military government ordered students to be mowed down as in the case of Odi situation to teach a lesson. Agents were planted among lecturers to spy on students and university staff. Some of the errand-boys were made political Vice Chancellors and their professorial positions were politically influenced. International Monetary Fund (IMF) gave out loans that the leaders used to destroy the outstanding educational systems in Nigeria. There was mass exodus of many brilliant lecturers that could not compete on political campus arenas from the university campus. Some left to join the rat race in the business world and others left Nigeria. Experienced and seasoned professors like the late Awojobi were sidelined. The political professors often silenced the lone voices of active and academic professors. Without bedevilling any of the military governments, the blame for the state of university education falls squarely on the academic staff and those that betrayed the institutions and the establishment. It soon became apparent how many lecturers became rich by selling out to any government in power, selling notes to students that wish to pass a course or selling out examination papers..." (Odetunde, 2006)
\end{abstract}

Resulting from the above is a scenario of low quality of schooling particularly with regards to poor physical infrastructures, lack of motivated staff, poor utilization of resources, content of curriculum, nature of teaching methods to mention a few. All these according to Igbuzor, (2006) can negatively impact on the urge to go to school. Meanwhile some Nigerian youth are not discouraged by the aforementioned hindrances. Few youths who are passionate about education utilizes the rot and moral decadence in the university system as steppingstone to gaining admission into higher institution. With the urge to getting university admission at all cost, they are ready to offer anything to whoever is in charge of it. Some university staff unscrupulously became admission peddlers; accepting different kinds of bribes from who ever has it and offer admission in return. This is done without regards to standard academic requirements. Consequently others are deprived of opportunities to gaining admission into the institution. The resultant desperation to avoid implications of illiteracy (such as poverty, low self esteem, lack of future prospect and security etc) makes the large portion of Nigerian youth to resort to ill-mannered struggles for socio-economic survival which often dismantle the defence of the nation and cripple the pace of economic growth in the country.

Today, the coming-of-age of Nigeria's economy rests primarily on its ability to harness its substantial youth population and leverage its economic potential for durable, long-term growth. In the country's economic capital, Lagos for instance, 273 civilians and 84 policemen were killed in separate criminal encounters between August 2000 and May 2001. Recent figures are even more disturbing: In 2008 alone, Niger Delta violence claimed 1,000 lives and accounted for 300 abductions, including those of 44 foreign workers. (Osalor, 2010) The reigning group now is Boko-Harram. Thiers is at alarming rate. The bewildering array of problems hindering the country's successful evolution from third-word stature calls for creative solutions based on a holistic outlook.

\title{
VI. The Implication on National Security
}

The paramount goal of education is the installation of moral, technical and epistemic values in individuals so they can be competently fit (both in mind and character) and useful to contribute meaningfully to the development of communities they find themselves. Education thus, is perceived as lubricant in the wheel of socio-economic and political progress of a nation. In fact, studies have revealed that educated and healthy people have the ability to contribute significantly to economic growth. (Becker, 1964; Schultz, 1960,) Human beings are the active agents who accumulate capital, exploit natural resources, build socio-economic and political organizations, and carry forward national projects for development. "Clearly a country which is unable to develop the skills and knowledge of its people and utilize them effectively in the national economy will be unable to develop anything else" (Harbison, 1973). Qualitative human resources education and youth orientation is sine-qua-non to nation building; it emancipates and empowers people to achieve economic and social freedom (Yesufu, 2000) thereby installing or inculcating in them the spirit of oneness and sense of allegiance to the nation. Equal access to education can facilitate the process of enthroning and cascading ethical values into the people thereby promoting the spirit of community oneness and collective responsibility. Osabuohien and Ogunrinola (2007) acknowledged that "education enhances political and health seeking behaviors among people". Similarly, Lochner and Moretti (2004) demonstrate that "years invested in education generate incentives greater than the private returns enjoyed by the individuals". In line with this, improvement in access to education is expected to improve in the people the spirit of social recognitions and equality, reduce feelings of frustration, aggression and intension to destroy. It will enhance feelings of belongingness, togetherness and love in them thereby propelling them to be brothers' keepers rather than brothers' killers. Thus, un-segregated access to education becomes one of the most powerful instruments for achieving people's loyalty towards their country and enables rapid social reform and peaceful coexistence.

In contrast, ill-trained man power is no doubt a threat to national security and nation building. When the best prepared students discover that negotiating the complicated thickets to tertiary institutions is confusing 
and overwhelming, or when they feel deprived of educational opportunities, the absence of a friendly face or guiding hand often leads to disengagement and disillusionment. Instead of a degree, they end up with debilitating debt that leaves them worse off than before. When the human element is untrained, half-trained, and or left illiterate, it easily becomes a social conduit for criminal activities that are difficult for the nation to handle. (Egwakhe and Osabuohien, (2009) The situation can be crippling especially when it is believed that lack of education is a result of pre-planed deprivation or designed denials, as it is in Nigerian today. Victims usually experience uncertainty and instability in every aspect of life (employment, securities, health safety, career advancement inter alia) and resultantly gullible to anti-developmental cajoles courtesy of rapacious and nefarious political leaders. It kills their aspirations and dooms them to vagabondage and crime. There have been situations in which the Nigerian youth especially, those of poor family background were used as tools for disrupting the political and democratic system through rigging, thuggery and ethnic conflicts. These factors in addition to economic mismanagement, leadership personal ambition or selfishness among others, were the factors that terminated the Nigerian First and Second Republic (Omodia, 2009) and has degenerated to the social and economic menace of corruption which has eaten deep into the heart of the nation. Today, youth hooliganism, hoodlumism and terrorism are the order of the day. The resultant threat lies on the peace, security and federal structure of the country. After all, empirical studies (such as that of Becker, 1964; Barro, 1991 \& 1999; and Bils and Klenow, 2000) have connected human capital to national security and economic growth. Corroborating this fact, Osalor (2010) submits that the problem of youth crime in Nigeria is inextricably linked to the state of its security.

What holds true for Nigeria and most other nations of equivalent human development indicators is that crime is often a means of survival among many youth. The idea is corroborated by the preponderance of property offenses (such as burglary, robbery, fraud etc,) across Nigeria. So much that shrivelling opportunities for sustainable employment and the resulting surge in crime are two of the biggest hurdles in the way of accelerated economic development. (Osalor, 2010) According to Umejie (2011) "while the direct cost of terrorism would include decline investors confidence and Foreign Direct Investment (FDI) the immediate effect are loss of man-hour of productivities to bureaucracy and security checks at both airports and offices across the country. No doubt, these issues would have telling effects on the economy on various fronts" Therefore corruption, national integration and insecurity, terrorism and political thuggery, among others, become parasite that truncates the seeds of national security and growth. It is a scenario that describes Nigerian democratic stability, peace and security as an impossible mission.

\section{Theoretical Insight}

Anomie theory, general strain theory, and relative deprivation theory have identified various types of factors which may induce delinquency and youth violence leading to unsafe social relations. The basic principle common to all three theories is that strain creates pressures that necessitate coping behaviours. Under some conditions, these coping behaviours may be deviant and detrimental to national security.

1 Anomie Theory: R K Merton (1938) argued that the widespread conformity to American culture in general, and the American obsession with economic success in particular, in which people must work hard and acquire certain possession or qualities in other to be economically buoyant and socially recognized, resulted in high levels of serious crime among people. The problem, according to Merton, is that despite the widespread belief in the possibility of upward social mobility, the social structure limits individuals' access to the goal of economic success through legitimate means. For example, while the probability of attaining economic success would be enhanced by getting a college education, not all members of American society are able to do so. Those lower on the socio-economic ladder are particularly vulnerable due to their relatively disadvantaged starting point in the race toward affluence. (Merton, 1938)

This disjunction between culturally ascribed goals (i.e., economic success) and the availability of legitimate means to attain such goals (i.e., social structural limits) in turn puts pressure on the cultural norms that guide what means should be used to achieve the culturally prescribed goal. Merton referred to this weakening of cultural norms as "anomie." A concept used by Durkheim's (1897) to mean the weakening of the normative order in society, or, as put differently by Davis (1959), how institutionalized social norms may lose their ability to regulate individuals' behaviour. Merton noted that institutionalized norms will weaken, and anomie will set in, in societies that place an intense value on economic success while restricting individuals' access to legitimate opportunities for upward socio-economic mobility, which in turn resulted in high levels of criminogenic anomie in society.

2 General Strain Theory: The general strain theory by Agnew (1992) argues that strain leads to bad emotions which may produce negative outcomes in individuals. He places more emphasis on strains resulting from failure to achieve positive valued goals such as money or status. The removal of positively valued stimuli (e.g., loss of a valued possession), and the presentation of negatively valued stimuli (e.g., physical abuse) will lead to violent behaviour in individual. People who suffers strain easily develop bad emotions including anger, 
when they see adversity as imposed by others, resentment when they perceive unjust treatment by others, and depression or anxiety when they blame themselves for the stressful consequence. These negative emotions, in turn, necessitate coping responses as a way to relieve internal pressure. Although not all responses are delinquent, general strain theory is particularly interested in delinquent adaptations.

The conditions under which strain may lead to crime was listed by Anew to include; a) strains that are seen as unjust, b) high in magnitude, c) associated with low social control, or d) other strains that create some incentive to engage in criminal coping. The last sets according to Agnew are most likely to lead to violence and delinquency. It is worthy of mentioning here that lack of unequal access to tertiary education is associated with all the four categories of factors leading to destructive behaviours.

General strain theory identifies various types of delinquent adaptations, including escapist (e.g., drug use), instrumental (e.g., property offences), and retaliatory (e.g., violent offences) outcomes. Coping via illegal behaviour and violence may be especially true for adolescents because of their limited legitimate coping resources, greater influence from peers, and inability to escape many stressful and frustrating environments. (Baron, 2003) Of the various types of negative emotions, anger has been identified as playing the key role in mediating the effect of strain on delinquency and violence. This is the case because anger "increases the individual's level of felt injury, creates a desire for retaliation/revenge, energizes the individual for action, and lowers inhibitions" (Agnew, 1992: 60)

3 Relative Deprivation Theory: The concept of relative deprivation directly measures people's subjective assessment of their economic position or other dimension of social comparison. Relative deprivation refers broadly to people's perceptions of their well-being relative to others in comparison. Well-being may be estimated based on a number of dimensions, including wealth, income, power and prestige. "Relative deprivation is also used to refer to the emotion one feels when making negatively discrepant comparisons" (Crosby, 1976) the theories argue that when attempting to understand the causes of crime which threatens peaceful coexistence among people, it is insufficient to examine objective factors such as poverty or inequality, and instead we must try to "itemize the factors that regulate the relationship between objective and subjective status" (Crosby, 1976). According to relative deprivation theory, objective conditions may have little relationship to people's behaviour, since their perceptions of these conditions may be at odds with the actuality. Although one's 'objective' position in social stratification system is important, one's subjective interpretation of that position may be even more important" (Agnew, 1995) Relative deprivation researchers explicitly recognize that people evaluate themselves relative to comparison others, and not all persons may choose the same comparison other. For this reason, relative deprivation is considered by its advocates to be more important when predicting people's behaviour, compared with more "objective" measures of deprivation such as poverty or inequality.

In summary, the current ubiquitous of socio-political thuggery, terrorism, kidnapping, killings and vandalism in Nigeria today is evidence that people experience chronic deprivation of various sorts which drives them to ill-coping behaviour and struggles that eventually constitutes major impediments to Nigerian national security and development.

\section{Conclusion}

Youth orientation and capacity development are panacea to the problems of insecurity, poverty, youth restiveness and unemployment currently prevalent in the country.(Olumade, 2009) It can be said with bold confidence that the most certain solution to the current trend of terrorism in Nigeria is a complete overhaul in educational policies, systems and accessibilities. This position was earlier echoed by Witte and Tauchen (1994) that time spent in schooling, irrespective of educational attainment, significantly decreases the time available for individuals to participate in criminal activities. There is thus, need for establishing educational institutions that will recognize and cater for such undeserved socio-economic class and stratification among Nigerian youth. Educational or literacy programme with global standards needed for youth reorientation, behavioural modification and reformation as well as capacity building need therefore be established in Nigeria. The emphasis on human behaviour is evident in Skinner's "Beyond Freedom and Dignity" who declared that:

"Human behaviour seems to be the cause of most of the World's problems: crime, poverty, pollution, war, overpopulation, even health-related problems such as cancer, sexually transmitted diseases, polio, malaria, etc.

The application of the physical and biological science alone would not solve these problems because the solution lies in another field... Better contraceptives will control population only if people use them. New methods of agriculture and medicine will not help if they are not practiced, and housing is a matter not only of buildings and cities but also of how people live. We need to make vast changes in human behaviour and it is not enough to 'use technology with a deeper understanding of human issues' or 'dedicate technology to man's spiritual needs' or to 'encourage technologists to look at human problems' what we need is a technology of behaviour" (B.F. Skinner, 1972)

This expression shows that in solving social problems, technology stops where human behaviour begins. In the same instance, the anomalistic, barbaric or destructive nature of an illegitimate child called "bastard" is not 
solely genetic because every child follows the same biological process, except proven otherwise. Differences in personalities occur, and deviants become so, simply because there is some form of discrepancies or deficiencies in the process of socialization that individuals go through. This is why some citizens resort to maladjusted behaviour which incidentally makes them bastards-citizens of the nation. Even those that inherit ancestral criminal traits can be re-modified through a properly designed, right-focused and well incentivized education. It is expedient to mention that this individual character is what usually metamorphoses to group activities and performance which can make or mar the progressive development of any nation especially when displayed by energetic youths. Equality in access to and attainment of educational qualifications is necessary if Nigerian youths are to become agents of progressive positive change in the country. Hence, there is need for government and educational policy makers to re-sharpen and repackage educational priorities by removing all barriers that prevents youths, especially the poor, from enjoying equal educational opportunities.

\section{The Way Forward}

Nigerian youths deserve higher education irrespective of their sex, race, ethnic, political connection or wealth, etc, especially in the universities and qualified candidates must not be denied access. The population of youths is increasing as the national population increases and there is more demand for university admission in recent time. What needs to be done is clear. We need to rise up to the challenges and change the course of events in Nigeria by putting education in a right perspective and footing. To do this, the following should be considered;

$>$ Those policies which increase access and opportunities like the Open University and Distance Learning System must be encouraged.

$>$ It is the limited space in our universities that forced NUC to bring up the policy of carrying capacity. Government should therefore adequately fund our universities so that there will be enough space to accommodate more students.

$>$ Also there is an urgent need for government to review the policies of catchment areas, quota system etc., in such a way that all inherent biases are removed and the teaming youth gain unrestricted access to higher education in Nigeria

$>$ The encouragement of private university is not so bad provided it is not meant solely for profit making. Effort should therefore be made to ensure that, first and foremost, private universities begin to operate for the purpose of achieving educational goals of the nation.

$>$ Our parents also should begin to rise up to their traditional duties; a situation where parents have gradually handed over the responsibility of child training to the formal system in schools is uncalled for. Charity begins from home and if parents take up their duties on their wards, it will go a long way in reducing youth restiveness and resultantly strengthening national peace and security.

$>$ Furthermore, the university management and administrators should also begin to fasten their belts as to ensuring good quality higher education deliveries which start from the selection processes. All practices of favouritism should be abolished by way of policy, and replaced with the principle of meritocracy.

- University teachers should be well remunerated and rescued from the economic torture that forces them to undervalue the essence of education for personal benefits.

\section{References}

[1] Igbuzor, O (2006) The State Of Education In Nigeria; a keynote address delivered at a roundtable organized by Civil Society Action Coalition On Education For All (csacefa) on $3^{\text {rd }}$ July, 2006, Garki, Abuja

[2] Subrahmanian, R. (2002), "Citizenship and the Right to Education" in IDS Bulletin Vol. 33 No. 2

[3] Federal Republic of Nigeria (2004) National policy on education Abuja: Federal Ministry of Information. $4^{\text {th }}$ Edition

[4] Moti U. G. (2010) The Challenges of Access to University Education in Nigeria, DSM Business Review v Vol. 2 , No. 2 (December, 2010)

[5] UNDP (2005), International Cooperation at a Crossroads: Aid, Trade \& Security in an unequal World. Human Development Report 2005

[6] Ofoha D (2011) Equalizing Educational Opportunity in Nigeria through Open and Distance Learning, Scaling up Quality Education for All National Open University of Nigeria

[7] UNESCO (2003) Education Webmaster World Conference on Higher Education Framework and Action, www.jyu.fi/unesco2003/conference.html Accessed 24th August 2011

[8] Ene, A.C. (2005), Access and Equity in University Education in Nigeria: Issues and Trends., in Akpa, G.O., Udoh, S.U., and Fagbamiye, E.O. (eds), Deregulating the Provision and Management of Education in Nigeria, Nigerian Association of Educational Administration and Planning (NAEAP), pp.55-62.

[9] Salawu, K.A., (1995) Education, social mobilization and the myth of equal education opportunity in Nigeria, Paper presented at the first National Conference, School of Arts and Social Sciences, Federal College of Education, Abeokuta, 22-27

[10] Ilusanya, R. (2008), Politics and Development of Tertiary Institutions in Nigeria, International Journal of Educational Management (IJEM), Vols. 5 \& 6, pp.166-178

[11] Akpotu, N.E. (2005), Deregulating the Nigerian University System: Implications for Equity and Access, in Akpan, G.O., Udoh, S.U., and Fagbamiye, E.O.(eds), Deregulating the Provision and Management of Education in Nigeria, Nigerian Association of Educational Administration and Planning (NAEAP), pp.57-62 
[12] Anugwom, E. E. (2009) Women, education and work in Nigeria, journal of Educational Research and Review Vol. 4 (4), pp. 127 134, April 2009 Available online at http://www.academicjournals.org/ERR ISSN 1990-3839 @ 2009 Academic Journals

[13] Egwakhe A. J and Evans S. C. Osabuohien (2009) Educational Backgrounds and Youth Criminality in Nigeria InFo Vol. 12, No. 1 April 2009 pp. 65-79

[14] Anachyochukwu, A. (2007, February 12) On a gunpowder keg. Tell Magazine, p.16.

[15] Wilson, J.Q., \& Herrnstein, R. (1985) Crime and human nature New York: Simon and Schuster.

[16] Freeman, R.B. (1991) Crime and the employment of disadvantaged youths, NBER Working Paper 3875

[17] Freeman, R.B. (1996). Why Do So Many American Young Men Commit Crime and What Might We Do about it? Journal of Economic Perspectives, 10, 25-42

[18] Oni, A. (2008, April 2). Robbers Snatch Bullion Van, Kill Two in Sagamu. The Punch, p. 5.

[19] Obe, I., \& Isine, F. (2008, Feb. 12). Gunmen Abduct Agape Chief in Ph. The Punch, p. 2.

[20] Alemika, E. E. \& Chukwuma, I. C. (2006) Criminal Victimization and Fear of Crime in Lagos Metropolis, Nigeria, Cleen Foundation Monograph Series, No. 1.

[21] Osalor, P. (2010) The Solution to Combating Youth Crime in Nigeria, the Daily Eagles, access on 11, November, 2011 at http://www.thedailyeagles.com/2010/10/14/the-solution-to-combating-youth-crime-in-nigeria.html

[22] Ojobo, J. A. (2008) Education: A catalyst for Women Empowerment in Nigeria. (Review Article) Ethiopian Journal of Education and Science, vol. 4 No. 1

[23] Obilade, S.O. (1992), .JAMB and University Admission in Nigeria, in Ajayi, T. and Alani, R.A. (eds), Contemporary Issues in Nigerian Education, Triumph Books Publishers, Ijebu-Ode, pp.48-59

[24] Ekpo A. H (1989) Manpower Development in Nigeria, In: SC Ogbuagu (Ed.): Strategy for National Development In Nigeria. Calabar, University of Calabar Press, pp. 143-154

[25] Odetunde C. (2006) The State of Higher Education In Nigeria, an unpublished document accessible at www.nigerdeltacongress.com/sarticles/state_of_higher-education_in_nig.htm Assessed on 25-11-2011

[26] Rose, P. (1998), "Willingness and Inability to Pay for Education: Cost Sharing in Malawi" in IDS December, 1998

[27] Igbuzor, O. (1992), Drug Revolving Fund as a Strategy to achieve Health for All Nigerians: A Case Study of University of Maiduguri Teaching Hospital. An unpublished Masters of Public administration thesis, University of Maiduguri, Nigeria

[28] Akpan, C. P. and Undie, J.A. (2007) Access to University in Nigeria: Issues and Problems, in Akpa, G.O., Udoh, S.U., and Fagbamiye, E.O. (Eds), Deregulating the Provision and Management of Education in Nigeria, Nigerian Association of Educational Administration and Planning (NAEAP), Lagos, pp.75-83

[29] Harbison F 1973. Human Resources as the Wealth of Nations, New York: Oxford University Press

[30] Yesufu, T. M. (2000). The human factor in national development in Nigeria, Ibadan, Nigeria: Spectrum Books Limited

[31] Osabuohien, E.S.C., \& Ogunrinola, I. O. (2007) Causes and Effects of Industrial Crises in Nigeria: Some Empirical Clarifications. Labour Law Review, 1(4), 75-93

[32] Lochner, L., \& Moretti, E., (2004). The effect of Education on Crime: Evidence from Prison Inmates, Arrests, and Self-Reports. American Economic Review, 94, 155-189.

[33] Omodia S. M. (2009) Manpower Development in Nigeria: Conceptual and Methodological Perspectives; Kamla-Raj 2009 J Soc Sci, 18(2): 113-117

[34] Becker, G. S. (1962). Investment in human capital: A theoretical perspective, Journal of Political Economy, 70(5), 9-49

[35] Barro, R. J. (1999). Human capital and growth in cross-country regressions, Swedish Economic Policy Review, 6(2), 237-277

[36] Bils, M., \& Klenow, P. J., (2000) Does Schooling Cause Growth? American Economic Review, 90, 1160-1183

[37] Umejie (2011) Nigeria; Counting Economic Cost of Terrorism, a Shout-African Article, Assessed on 25-11-20011 at www.shoutafrica.com/politicts/nigeria-counting-economic-cost-of-terrorism.html

[38] Merton, R.K. (1938) Social structure and anomie American Sociological Review, 3, 672-682

[39] Durkheim, E. (1897). Suicide: A Study in Sociology. New York: Free Press.

[40] Davis, J. (1959). A formal interpretation of the theory of relative deprivation Sociometry, 22(4), 280-296

[41] Agnew, R. (1992). Foundation for a general strain theory of crime and delinquency Criminology, 30, 47-87

[42] Baron, S. W. (2003) Self-control, social consequences, and criminal behavior: Street youth and the general theory of crime. Journal of Research in Crime and Delinquency, 40(4), 403-425

[43] Crosby, Faye. (1976). A model of egoistic relative deprivation, Psychological Review, 83(2), 85-113

[44] Agnew, R. (1995). The contribution of social psychological strain theory to the explanation of crime and delinquency, In Freda Adler and William S. Laufer (Eds.), The legacy of anomie theory (pp. 113-138). New Brunswick, NJ: Transaction

[45] Olumade S. A. (2008) University Education and Youth Entrepreneurship in Nigeria.

[46] Skinner, B. F. (1972) Beyond Freedom and Dignity $\left(7^{\text {th }}\right.$ Edition) Banta Books 